\title{
Solar nanophotocatalytic pretreatment of seawater: process optimization and performance evaluation using response surface methodology and genetic algorithm
}

\author{
Varghese Manappallil Joy ${ }^{1} \cdot$ Shaik $_{\text {Feroz }}^{2} \cdot$ Susmita Dutta $^{1}$ (I)
}

Received: 7 July 2020 / Accepted: 21 December 2020 / Published online: 14 January 2021

(c) The Author(s) 2021

\begin{abstract}
In reverse osmosis seawater treatment process, membrane fouling can be mitigated by degrading organic pollutants present in the feed seawater. The present study evaluates the effectiveness of employing solar photocatalysis using $\mathrm{TiO}_{2} / \mathrm{ZnO} / \mathrm{H}_{2} \mathrm{O}_{2}$ to pretreat reverse osmosis (RO) feed seawater under solar irradiation. Process optimisation and performance evaluation were undertaken using response surface methodology-desirability function and RSM integrated with genetic algorithm (RSM-GA). Statistical analysis was performed to determine the interactive relationships and main effects of input factors such as $\mathrm{TiO}_{2}$ dosage, $\mathrm{H}_{2} \mathrm{O}_{2}$ dosage, $\mathrm{pH}$, reaction time and $\mathrm{ZnO}$ dosage. The performance evaluation was determined in terms of percentage removal of total organic carbon (TOC) and chemical oxygen demand (COD). The obtained optimum values using RSM-GA evaluation for TOC and COD removal were found to be 76.5\% and 63.9\%, respectively. The predicted RSM-GA results correspond well with the experimental results (TOC removal $=73.3 \%$, COD removal $=61.2 \%$ ). Utilization of renewable solar energy coupled with optimum utilisation of nanophotocatalysts enables this technique to be a unique treatment process for RO pretreatment of seawater and membrane fouling mitigation.
\end{abstract}

Keywords Seawater pretreatment $\cdot$ Reverse osmosis (RO) membrane fouling $\cdot$ Solar nanophotocatalysis $\cdot$ Central composite design

\section{Introduction}

Seawater is becoming an increasingly significant water source globally due to high stress on freshwater availability and contamination issues. Based on lower installed capacity, seawater reverse osmosis (SWRO) surpasses all other thermal technologies like multi-stage flash (MSF) and multieffect distillation (MED) and dominates the global desalination scenario. However, the performance of reverse osmosis (RO) membrane desalination systems majorly depends on fouling control and pretreatment processes to reduce contaminant loading (Amy et al. 2017). Fouling due to presence

Susmita Dutta

susmita_che@yahoo.com

1 Department of Chemical Engineering, National Institute of Technology Durgapur, Durgapur 713209, India

2 Department of Mechanical Engineering and Deanship of Research, Prince Mohammad Bin Fahd University, Alkhobar, Kingdom of Saudi Arabia of organics detrimentally affect the desalination systems by decreasing permeate flux, reducing energy efficiency due to high pressure drop and causing serious damage to the RO membranes (Weinrich et al. 2016). Many experimental studies revealed that the biofilm that affects membrane consists of around 50\% organic matters, out of which about $40 \%$ are organic acids. RO membrane biofouling results in higher operating pressure, repeated chemical cleaning and reduces the life of the membrane (Matin et al. 2011).

Biofouling problem is very crucial in the Middle East region, where around $75 \%$ of $\mathrm{RO}$ membrane facilities are affected. Moreover, this is the region where the most considerable amount of desalted water is produced in the world (Khedr 2011). As per the literature survey, in most of the SWRO plants, humic substances (organic contaminants) are the main contributor of fouling to the RO membranes. If TOC of the seawater is less than $0.5 \mathrm{mg} / \mathrm{L}$, the presence of microbial foulants is minimal, and the feed seawater has very low biofouling potential. For TOC values in the range of $0.5-2.0 \mathrm{mg} / \mathrm{L}$, the RO feed seawater has moderate fouling potential. However, if the TOC exceeds $2.0 \mathrm{mg} / \mathrm{L}$, the 
biofouling potential is very high (Voutchkov 2017). Therefore, the deterioration of these contaminants from the RO feed seawater is a significant concern to improve the performance and cost-efficacy of SWRO systems. Advanced oxidation process with suitable photocatalysts can degrade persistent pollutants from the feed water. Remediation of recalcitrant pollutants is directly linked to the development of hydroxyl radicals $\left(\mathrm{OH}^{-}\right)$as it can degrade organic contaminants in the aquatic environment (Malato et al. 2016). Previous seawater decontamination studies revealed the advanced oxidation of recalcitrant pollutants by UV/photocatalysts methodology, where the processes either oxidised or entirely mineralised the model organic compounds. Rubio et al. (2013) evaluated the feasibility of disinfecting seawater by $\mathrm{UV} / \mathrm{TiO}_{2}$ immobilized process. The study proved that $\mathrm{TiO}_{2}$ photocatalysis has faster disinfection kinetics than UV alone for different bacterial disinfections. Jiménez et al. (2017) reported that the addition of $\mathrm{TiO}_{2}$ accelerated the photo-Fenton process in treating cleaning waters from seawater desalination reverse osmosis membranes for recycling purposes.

Heterogeneous photocatalysis is an advanced oxidation technology capable of degrading a wide range of organic compounds present in the aquatic medium. Photocatalytic oxidation reactions have the potential to degrade the organic compounds to water and carbon dioxide and can provide clean and energy-saving technology for treating contaminated water. Due to solar irradiation, the photon having energy equal or greater than the semiconductor bandgap hits the catalyst to excite an electron from the valence band to the conduction band, resulting in the formation of electron-hole pair. These two entities are highly reactive and are involved in continuous oxidative and reductive reactions on semiconductor surface (Ab Aziz et al. 2016). As a result, hydroxyl radicals $\left(\mathrm{OH}^{\prime}\right)$ are generated by the oxidation of $\mathrm{H}_{2} \mathrm{O}$ or $\mathrm{OH}^{-}$on the surface. The $\mathrm{OH}$ radicals are highly powerful oxidants which can degrade recalcitrant organic pollutants from the medium. A typical semiconductor photocatalyst should be able to absorb near UV or visible light, chemically inert, photostable and inexpensive (Azevedo et al. 2009). Titanium dioxide $\left(\mathrm{TiO}_{2}\right)$ is a widely used semiconductor catalyst which shows promising characteristics even though in pure form, it gets activated only in UV region.

Although organic degradation of seawater by photocatalysis is comparatively lower due to electron scavenging issues, some of the past research studies showed very positive results in improving overall organic removal efficiency. Kaneva et al. (2015) studied the photocatalytic degradation of model organic in distiled and seawater by employing lanthanide modified $\mathrm{ZnO}$ under UV-light irradiation. It was observed that the photocatalyst achieves contaminant mineralization in minimum irradiation time. Ji et al. (2017) conducted a research study about photocatalytic removal of diesel pollutants from seawater using $\mathrm{ZrO}_{2} / \mathrm{TiO}_{2}$ under visible light. In their work, photocatalyst effectiveness was investigated under the influence of various factors like doping ratio of catalyst, $\mathrm{pH}$ value, catalyst dosage, initial concentration of diesel and illumination time. They achieved 87.74\% degradation of diesel pollutants from seawater under visible light photocatalysis. Many research studies enhanced the production rate of powerful oxidants by chemical addition, excitation energy (sunlight/UV), photocatalysts $\left(\mathrm{TiO}_{2}, \mathrm{ZnO}, \mathrm{Fe}_{2} \mathrm{O} 3, \mathrm{CdS}, \mathrm{ZnS}\right)$ and combining two or more advanced oxidation process such as $\left(\mathrm{TiO}_{2} /\right.$ Fenton-UV), ozonation- $\mathrm{TiO}_{2}$ and $\mathrm{TiO}_{2}$-Fenton-sunlight (Aljuboury et al. 2015). Yang et al. (2018) applied $\mathrm{ZnO}$ modified $\mathrm{TiO}_{2}$ nanocomposites for organic pollutant removal from feedwater and reported enhanced degradation performance compared to pure $\mathrm{TiO}_{2}$. In the present study of seawater photocatalyst oxidation treatment, membrane fouling organic contaminants are degraded using $\mathrm{TiO}_{2}-\mathrm{ZnO}$ catalysts under solar irradiation.

Even though the semiconductor photocatalytic process is extensively employed in the treatment of effluents and other wastewater, little research studies were attempted in the field of pretreatment of RO desalination feed seawater. Several previous researchers applied photocatalytic technology for organics treatment from air, soil and wastewater, but very little work has been reported on seawater treatment, which may be due to the complexity of seawater composition. Optimization of $\mathrm{TiO}_{2}-\mathrm{ZnO}-\mathrm{H}_{2} \mathrm{O}_{2}$ solar photocatalytic degradation of organics from seawater through DOE-based RSM-GA is still not available as per the knowledge of present research group concerned. This research paper presents for the first time, the application of RSM-GA optimization and solar nano $\mathrm{ZnO}-\mathrm{TiO}_{2}-\mathrm{H}_{2} \mathrm{O}_{2}$ photocatalysis for the degradation of organics from seawater. The goal of this research study is to design and optimize a renewable energy-based photocatalytic process to mitigate $\mathrm{RO}$ membrane fouling in desalination plants.

The present study attempts to mitigate the fouling issues by photocatalytic degradation of organics and microorganism, using real seawater samples collected nearby a SWRO plant in Muscat, Oman. The current study evaluates the effectiveness of employing solar photocatalysis of $\mathrm{TiO}_{2} / \mathrm{ZnO} / \mathrm{H}_{2} \mathrm{O}_{2}$ process to pretreat $\mathrm{RO}$ feed seawater under solar irradiation. Process optimization and performance evaluation were undertaken using response surface methodology-desirability function (RSM-DF) and RSM integrated with genetic algorithm (RSM-GA) approach. Statistical analysis was performed to determine the interactive relationships and main effects of input factors such as $\mathrm{TiO}_{2}$ dosage, $\mathrm{H}_{2} \mathrm{O}_{2}$ dosage, $\mathrm{pH}$, reaction time (RT) and $\mathrm{ZnO}$ dosage. The performance evaluation was determined in terms of percentage removal of total organic carbon (TOC) and chemical oxygen demand (COD). Finally, the prediction accuracies of 
optimum conditions by RSM-DF and RSM-GA techniques were compared, and the best solution is suggested for the overall process improvement in RO desalination seawater pretreatment.

\section{Materials and methods}

\section{Materials and solar radiant flux measurement}

Seawater sample, $2 \mathrm{~km}$ away from the shore, was collected in sterile bags and kept in the freezer $\left(5^{\circ} \mathrm{C}\right)$ until it was taken for solar photocatalytic treatment. The samples were characterized before the treatment to determine COD and TOC. The catalysts used were nano zinc oxide ( $\mathrm{ZnO}, 99.9 \%$ Pure, APS: $20 \mathrm{~nm}$ ), obtained from mkNANO, Canada and titanium dioxide $\left(\mathrm{TiO}_{2}\right)$ Aeroxide $\mathrm{P}-25$ manufactured by Evonik Industries, Germany and $0.1 \mathrm{~N}$ of $\mathrm{NaOH}$ and $\mathrm{HCl}$ of $0.1 \mathrm{~N}$ were used for adjusting $\mathrm{pH}$. COD test was done by using COD HR+ (0-15,000 $\mathrm{mL} / \mathrm{L})$ reagent vial from CHEMetrics, COD digester and COD HR photometer. TOC of each sample was determined by using TOC analyser (LCSH/CSN) supplied by SHIMADZU, Japan. Before analyzing TOC and COD, each sample was filtered using $0.22 \mu \mathrm{m}$ Millipore Durapore membrane (150 mm-diameter and ashless-40).

The silt density index (SDI) of the seawater sample before and after photocatalytic treatment was calculated using SDI kit (SDI-2000, directSDI, 115-120 v, $60 \mathrm{~Hz}$, USA). The average solar radiant flux was measured using KIPP $\&$ ZONEN-CMP 21 Pyranometer and found to be approximately $670 \mathrm{~W} / \mathrm{m}^{2}$. All experimental runs were carried out from 11 a.m. to 2 p.m. so that maximum UV radiation was received for photocatalytic treatment. The UVS-E-T radiometer supplied by KIPP \& ZONEN was used to measure UV irradiance as per ISO 17166:1999, CIE S 007/E-1998 procedure. UV irradiance was determined by using Eq. 1 .

$I_{\text {solar }}=E / C_{\mathrm{s}}$

where $C_{\mathrm{s}}$ is the radiometer sensitivity constant $\left((\mu \mathrm{V} / \mathrm{W}) / \mathrm{m}^{2}\right)$, $E(\mu \mathrm{V})$ is the voltage output, and $I_{\text {solar }}\left(\mathrm{W} / \mathrm{m}^{2}\right)$ is the solar irradiance.

\section{Experimental procedure}

The experimental setup of $\mathrm{TiO}_{2} / \mathrm{ZnO} / \mathrm{H}_{2} \mathrm{O}_{2} /$ solar nanophotocatalytic reactor system is shown in Fig. 1. Five borosilicate glass tubes $(650 \mathrm{~mm}$ length $\times 22 \mathrm{~mm}$ inner diameter and $2 \mathrm{~mm}$ thickness) were used for seawater recirculation exposed to solar irradiation. The setup consists of a glass recirculation tank $(2.5 \mathrm{~L})$ subjected to stirring with magnetic stirrers. Seawater solution was run through the tubular photocatalytic reactor by means of a peristaltic pump (PERCOM
N-M-II Peristaltic pump, 0.5-350 rpm, 0-2100 mL/min, 48 Watts) at a flow rate of $1.8 \mathrm{~L}$ per minute. The flow rate was fixed constant for all experimental runs. The $\mathrm{pH}$ of the solution was varied from 2 to 8 as per the factor settings of each run, prescribed by one-factor-at-a-time (OFAT) study and the central composite design (CCD) matrix. Samples were taken for TOC and COD analysis at respective reaction time interval settings, which was varied from 30 to $210 \mathrm{~min}$. The tilt of the reactor was fabricated $\left(19^{\circ}-24^{\circ}\right.$ angle with horizontal) to make it align with solar angle and was conformable to the location latitude $\left(23^{\circ} 40^{\prime} 12.97^{\prime \prime} \mathrm{N}\right)$. Parabolic reflectors were installed beneath the reactor tubes to make the solar irradiation to be reflected and diffused to the tubes at optimum intensity. The magnetic stirring, aeration using an air pump $(4.29 \mathrm{~L} / \mathrm{min})$ and recirculation using peristaltic pump ensured proper mixing and enough supply of oxygen required for photocatalytic reaction. The aeration process and the resulting air bubbles acted as a source of oxygen to enhance the overall photocatalytic degradation rate (Tony et al. 2009). The post-separation of the catalysts is accomplished by overnight settling process in a sedimentation tank. Since the $\mathrm{pH}$ of the seawater reaches near to the point of zero charge $\left(\mathrm{pH}_{\mathrm{PZC}}\right)$ after the photocatalytic treatment, the catalyst surface charge neutralisation improves the sedimentation and aggregation process.

\section{Effect of operating variables on TOC and COD removal}

The initial concentration of TOC of seawater samples used in this experimental study is found to be less than $3.89 \mathrm{mg} / \mathrm{L}$. In seawater reverse osmosis (SWRO) plants, an increase in initial TOC value beyond a threshold value $(2.0-2.5 \mathrm{mg} / \mathrm{L})$ is found to elevate enhanced biofouling of RO membranes. Hence, the main objective of this research study is to reduce the biofouling potential of seawater by degrading the TOC level well below the critical value of $2.0 \mathrm{mg} / \mathrm{L}$. To evaluate the effect of input variables on the percentage removal of TOC and COD, variables such as $\mathrm{TiO}_{2}$ dosage $(0.1-0.8 \mathrm{~g} / \mathrm{L})$, $\mathrm{ZnO}$ dosage $(0.1-0.8 \mathrm{~g} / \mathrm{L}), \mathrm{H}_{2} \mathrm{O}_{2}$ dosage $(0.2-1.0 \mathrm{~mL} / \mathrm{L})$, solar irradiation time $(30-210 \mathrm{~min})$ and $\mathrm{pH}(2-8)$ were varied sensibly during the photocatalytic reactions. For the initial range finding and screening, one-factor-at-a-time (OFAT) experimental design was followed. OFAT enables to detect more quickly if a factor has any effect on the response variable of interest and is, therefore, a sequential learning methodology (Sen et al. 2017). Among the five input factors, at first, the effect of $\mathrm{TiO}_{2}$ dosage was investigated. $\mathrm{ZnO}$ dosage, $\mathrm{H}_{2} \mathrm{O}_{2}$ dosage, solar irradiation time and $\mathrm{pH}$ were kept constant at $0.5 \mathrm{~g} / \mathrm{L}, 0.5 \mathrm{~mL} / \mathrm{L}, 180 \mathrm{~min}$ and 8 , respectively. In the second stage, to identify the effect of $\mathrm{ZnO}$ dosage on percentage removal of TOC and COD, it was varied from 0.1 to $0.8 \mathrm{~g} / \mathrm{L}$, keeping $\mathrm{v}$ dosage, solar irradiation time and 


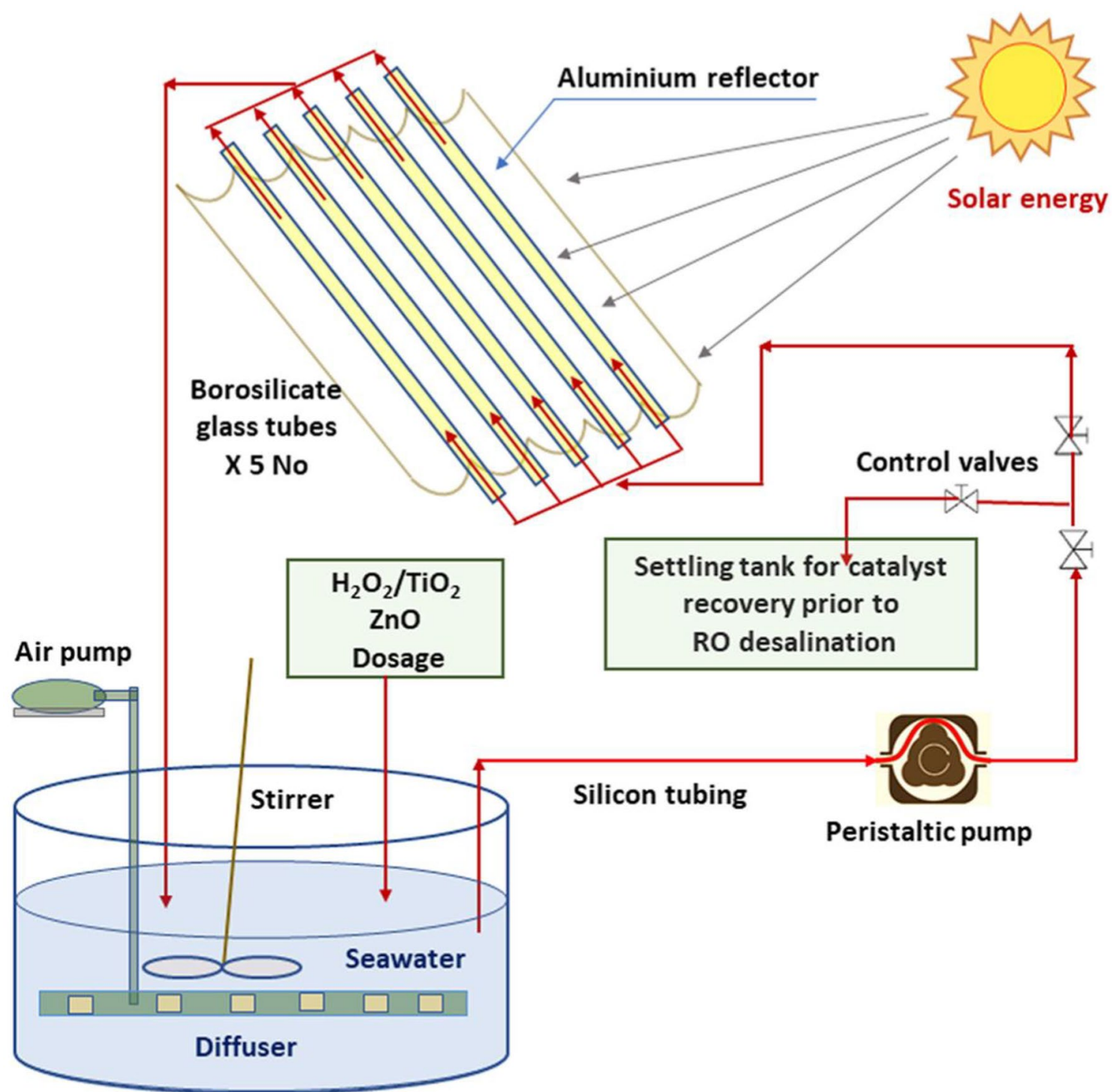

Fig. 1 Experimental setup of Solar $/ \mathrm{TiO}_{2} / \mathrm{ZnO} / \mathrm{H}_{2} \mathrm{O}_{2}$ photocatalytic reactor system

$\mathrm{pH}$ at $0.5 \mathrm{~mL} / \mathrm{L}, 180 \mathrm{~min}$ and 8 , respectively. However, the $\mathrm{TiO}_{2}$ dosage which gave the best result in the initial OFAT experiments was selected for the current set of experiments. Similarly, $\mathrm{H}_{2} \mathrm{O}_{2}$ dosage, irradiation time and $\mathrm{pH}$ were varied in the range of $0.2-1.0 \mathrm{~mL} / \mathrm{L}, 30-210 \mathrm{~min}$ and $2-8$, respectively, keeping other input factors constant at the values in which they gave best TOC and COD removal. The results from OFAT study were used to find the levels of input variables.

TOC and COD removal (\%) were calculated by using Eqs. 2 and 3, respectively.

$\mathrm{TOC}_{\text {removal }}(\%)=\frac{T_{0}-T_{t}}{T_{0}} \times 100$ where $T_{0}$ is the initial TOC of seawater before treatment and $T_{t}$ represents the total organic carbon content after " $t$ " minutes of solar irradiation.

$\mathrm{COD}_{\text {removal }}(\%)=\frac{C_{0}-C_{t}}{C_{0}} \times 100$

where $C_{0}$ is the initial COD of seawater before photocatalytic treatment and $C_{t}$ represents the chemical oxygen demand after " $t$ " minutes of solar irradiation.

\section{Design of experiments and statistical analysis}

DOE-based response surface methodology (RSM) was used for experimental design and process optimization 
with Design-Expert (version 11, Stat-Ease, USA) software. Response surface methodology is a statistical tool utilising experimental data generated from the respective design to optimize and model any system in which the response variable under study is affected by crucial input factors (Chatterjee et al. 2012). RSM is a competent technique for process optimization, strategically computing optimum condition for a multivariate process. This technique helps to establish relationships between response variables and controllable input variables or process factor, but the main limitation of this technique is that it can assume only nonlinear quadratic correlation and therefore requires a narrow search window (Desai et al. 2008), finding which requires either new OFAT experiments or good prior knowledge of the system. Central composite design (CCD) is a typical RSM technique well suited for fitting a second-order curve and optimizing significant process parameters that influence the dependent variables.

The efficiency of the photocatalytic treatment is analysed in term of percentage removal of COD and TOC by conducting experimental runs through a CCD matrix. Each independent process factor is varied between coded -1 (low), 0 (centre) and +1 (high) levels at predetermined ranges calculated from the preliminary OFAT experimentation. CCD-RSM model was generated using data from 48 experimental runs $\left(=2^{n}+2 n+n_{c}\right.$, where $n$ is the number of factors which is equal to 5). Thus, CCD in this research work consists of $2^{n}$ factorial runs augmented with $2 n$ axial experiments, and $n_{c}$ is the number of central runs. The central runs are used as replications to evaluate the reproducibility of the data and experimental errors. The sequence of experimental runs is randomized to avoid random process variations. The outcome from each run was tabulated into the Design-Expert software to correlate the responses with input factors. The second-degree polynomial equation for a response that explains its behaviour is shown in Eq. 4. Since each input factor is set at three levels, the appropriate model for the response follows a quadratic model.

$Y=\beta_{0}+\sum_{j=1}^{k} \beta_{j} X_{j}+\sum_{j=1}^{k} \beta_{j j} X_{j}^{2}+\sum_{j<l}^{k} \beta_{j l} X_{j} X_{l}+e_{i}$

where $Y$ is the response forecasted, $\beta_{0}$ is the regression coefficient, $\beta_{j}$ is the coefficient of linearity, $\beta_{i j}$ is the coefficient of interaction, and $\beta_{j j}$ is the quadratic coefficient, $X_{i}$ and $X_{j}$ are input variables, $k$ represents the number of input factors, and $e_{i}$ denotes random process error. After generating a quadratic RSM model, it's input space is optimized using desirability function (DF) method. The optimal solution from RSM-DF is again compared by using RSM integrated genetic algorithm (GA) approach.

Genetic algorithm (GA), an artificial intelligence-based stochastic nonlinear optimization method, can be used to optimize the input space of any well-trained models like artificial neural network (ANN) model (Dibaba et al. 2016). While GA may be used to configure optimum ANN model, the same ANN model, or any RSM model, can be used as an objective (fitness) function within GA to generate optimum function values and process settings (Sharma et al. 2017; Kumar and Kumar 2019). After the development of a generalized ANN or RSM model, the GA approach is used to find the optimum process settings. Therefore, GA is an optimization strategy developed based on the principles of natural selection that start with the selection of fittest individuals from a population (Mukherjee et al. 2019). A solution of GA is characterized by a chromosome having a fitness value which ensures the solution to be competent enough. The parameters of GA may comprise of a set of the population consist of chromosomes and genes, selection, crossover, mutation, fitness and fitness function (Abdollahi et al. 2019). The algorithm begins with a random initial set of population and a selection process based on fitness value to create the next generation. Crossover and mutation principles are used to combine genes for the next iteration and apply stochastic changes to reproduce population (Hassani et al. 2018). Upon the successive generations, the population evolves, and the optimum solution is determined. In the current study, the optimum solution obtained from RSM-GA simulation is compared with RSM optimal conditions generated by Design-Expert software.

\section{Results and discussion}

\section{Characterization of seawater}

The seawater sample, collected from Muscat, Gulf of Oman, was characterized in terms of total organic carbon (TOC), $\mathrm{pH}$, salinity, etc. Table 1 summarizes the physicochemical characteristics of the sample seawater collected before

Table 1 Characteristics of seawater sample from the Gulf of Oman, $2.0 \mathrm{~km}$ away from the shore, at the location $23^{\circ} 41.921^{\prime} \mathrm{N}, 058^{\circ}$ $11.115^{\prime} \mathrm{E}$

\begin{tabular}{|c|c|c|c|}
\hline No & Parameter & Unit & $\begin{array}{l}\text { Range of con- } \\
\text { centrations in } \\
\text { seawater }\end{array}$ \\
\hline 1 & $\mathrm{Ph}$ & - & $7.5-8.1$ \\
\hline 2 & Conductivity & $\mathrm{mS}$ & $52.34-56.22$ \\
\hline 3 & Salinity & $\mathrm{mg} / \mathrm{L}$ & $34,000-34,400$ \\
\hline 4 & Turbidity & NTU & $1.50-1.65$ \\
\hline 5 & Dissolved oxygen, DO & $\mathrm{mg} / \mathrm{L}$ & $5.12-5.38$ \\
\hline 6 & Total dissolved solids, TDS & $\mathrm{mg} / \mathrm{L}$ & $53,200-53,400$ \\
\hline 7 & Chemical oxygen demand, COD & $\mathrm{mg} / \mathrm{L}$ & $4.9-5.78$ \\
\hline 8 & Total organic carbon TOC & $\mathrm{mg} / \mathrm{L}$ & $2.94-3.89$ \\
\hline
\end{tabular}


each experiment. The silt density index (SDI) of the seawater samples before and after photocatalytic treatment (under optimum conditions) is found to be 0.45 and 0.38 , respectively.

\section{Effect of process input factors on the removal of TOC and COD}

For determining the significance and optimum ranges of operating variables, OFAT study has been conducted by judiciously varying one input factor at a time while keeping other factors at constant levels. At first, $\mathrm{TiO}_{2}$ dosage has been varied in the range of $0.1-0.8 \mathrm{~g} / \mathrm{L}$, while $\mathrm{ZnO}$ dosage, $\mathrm{H}_{2} \mathrm{O}_{2}$ dosage, solar irradiation time and $\mathrm{pH}$ were kept constant at $0.5 \mathrm{~g} / \mathrm{L}, 0.5 \mathrm{~mL} / \mathrm{L}, 180 \mathrm{~min}$ and 8 , respectively. The TOC and COD removal have been measured after each photocatalytic reactions, as shown in Fig. 2a. It was observed that maximum TOC removal $(49.5 \pm 4.25 \%)$ and COD removal $(40.5 \pm 4.12 \%)$ occurred at $\mathrm{TiO}_{2}$ dosage of $0.45 \mathrm{~g} / \mathrm{L}$ and higher dosages resulted in reduced organic removal efficiency. Similar results were obtained with $\mathrm{ZnO}$ dosage (Fig. 2b). In a previous study to remove organics from petroleum wastewater, Dheea et al. observed a similar trend at higher concentrations of $\mathrm{TiO}_{2}$ and $\mathrm{ZnO}$ catalysts (Aljuboury et al. 2016). Turbidity caused by a higher concentration of catalysts hinders the penetration of light into the reactor and hence reduced organic removal efficiency is observed (Malato et al. 2009). In the current study, the values of $\mathrm{TiO}_{2}$ and $\mathrm{ZnO}$ dosages obtained from first two sets of experiments were used in the third OFAT study where maximum removal (TOC removal $=48.1 \pm 4.15 \%$, COD removal $=41.8 \pm 3.84 \%$ ) is achieved at $\mathrm{H}_{2} \mathrm{O}_{2}$ dosage of $0.6 \mathrm{~mL} / \mathrm{L}$ (Fig. 2c). Generally, the degradation efficiency increases with $\mathrm{H}_{2} \mathrm{O}_{2}$ dosage in the initial phase of the photocatalytic reaction. However, after an optimal threshold value, a further increase in $\mathrm{H}_{2} \mathrm{O}_{2}$ concentration inversely
Fig. 2 a TOC removal (\%) and $\mathrm{COD}$ removal (\%) at $\mathrm{ZnO}$ dosage $0.5 \mathrm{~g} / \mathrm{L}, \mathrm{H}_{2} \mathrm{O}_{2}$ dosage $0.5 \mathrm{~mL} / \mathrm{L}$, solar irradiation time $180 \mathrm{~min}$ and $\mathrm{pH} 8$ for different $\mathrm{TiO}_{2}$ dosage; b TOC removal $(\%)$ and COD removal (\%) at $\mathrm{TiO}_{2}$ dosage $0.45 \mathrm{~g} / \mathrm{L}, \mathrm{H}_{2} \mathrm{O}_{2}$ dosage $0.5 \mathrm{~mL} / \mathrm{L}$, solar irradiation time $180 \mathrm{~min}$ and $\mathrm{pH} 8$ for different $\mathrm{ZnO}$ dosage; $\mathbf{c}$ TOC removal (\%) and COD removal (\%) at $\mathrm{TiO}_{2}$ dosage $0.45 \mathrm{~g} / \mathrm{L}$, $\mathrm{ZnO}$ dosage $0.45 \mathrm{~g} / \mathrm{L}$, solar irradiation time $180 \mathrm{~min}$ and pH 8 for different $\mathrm{H}_{2} \mathrm{O}_{2}$ dosage; d TOC removal (\%) and COD removal (\%) at $\mathrm{TiO}_{2}$ dosage $0.45 \mathrm{~g} / \mathrm{L}, \mathrm{ZnO}$ dosage $0.45 \mathrm{~g} / \mathrm{L}$, $\mathrm{H}_{2} \mathrm{O}_{2}$ dosage $0.6 \mathrm{~mL} / \mathrm{L}$, solar irradiation time $180 \mathrm{~min}$ for different $\mathrm{pH}$

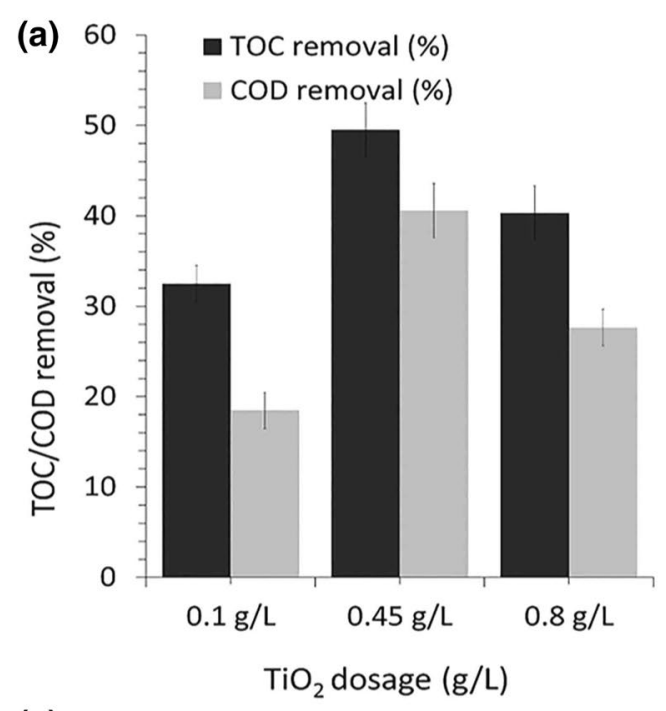

(c)

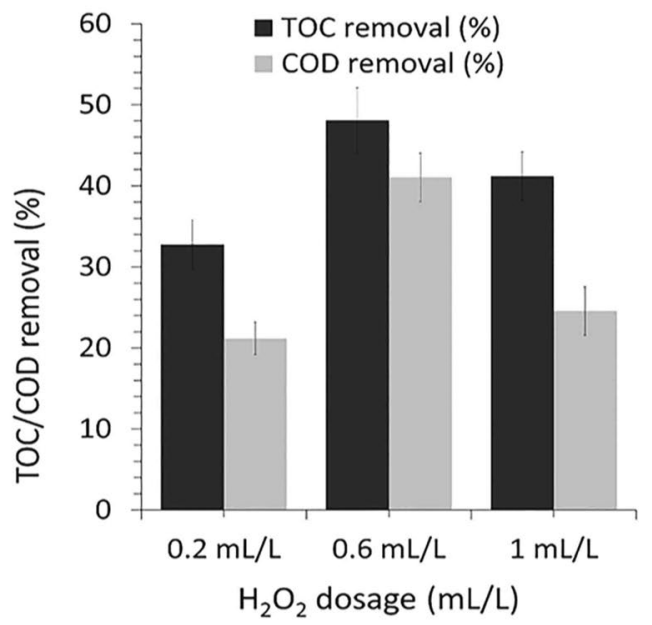

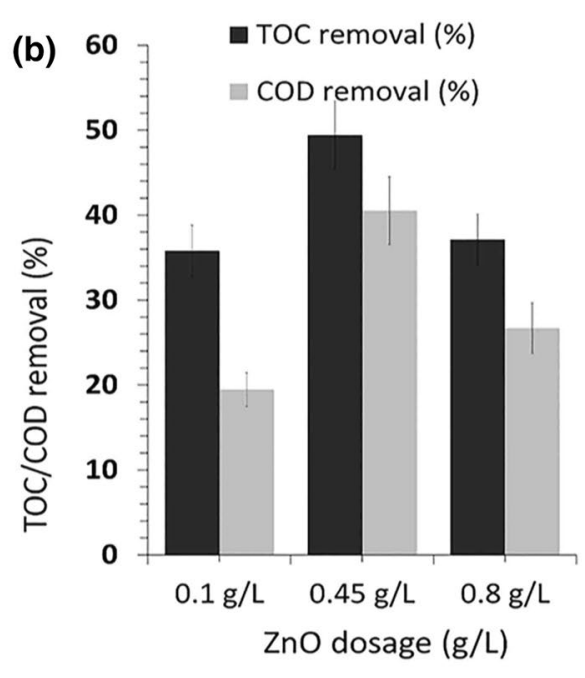

(d)

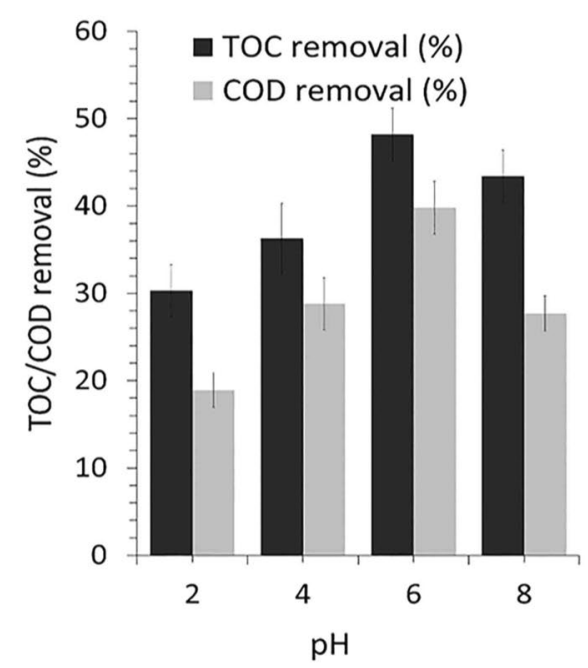


affects organic degradation due to the distinct nature of $\mathrm{H}_{2} \mathrm{O}_{2}$ as a radical scavenger. In the fourth sets of experiments, $\mathrm{pH}$ was varied from 2 to 8 (Fig. 2d) where maximum organic degradation (TOC removal $=48.3 \pm 3.32 \%$, COD removal $=39.9 \pm 3.45 \%)$ was achieved at $\mathrm{pH} 6, \mathrm{TiO}_{2}$ dosage $0.45 \mathrm{~g} / \mathrm{L}, \mathrm{ZnO}$ dosage $0.45 \mathrm{~g} / \mathrm{L}, \mathrm{H}_{2} \mathrm{O}_{2}$ dosage $0.6 \mathrm{~mL} / \mathrm{L}$ and solar irradiation time of $180 \mathrm{~min}$. At acidic operational $\mathrm{pH}$, the surface charge for $\mathrm{TiO}_{2}$ becomes positive and exerts an attractive electrostatic force on anionic organic composites which in turn enhances the photocatalytic degradation. Figure 3 shows TOC removal and COD removal at $\mathrm{TiO}_{2}$ dosage $0.45 \mathrm{~g} / \mathrm{L}, \mathrm{ZnO}$ dosage $0.45 \mathrm{~g} / \mathrm{L}, \mathrm{H}_{2} \mathrm{O}_{2}$ dosage $0.6 \mathrm{~mL} / \mathrm{L}$ and $\mathrm{pH} 6$ for different solar irradiation time. It was found that maximum TOC removal $(48.2 \pm 2.75 \%)$ and COD removal $(40.7 \pm 3.13 \%)$ occurred at a solar reaction time (RT) of $150 \mathrm{~min}$ and further increment in time does not give any improvement in organic removal efficiency. Since the irradiation time depends on the initial concentration and ionic state of various organic contaminants, after a certain threshold, the degradation rate remains unchanged.

\section{Five-factor centre composite design (CCD)}

The results obtained from the OFAT study was utilized in identifying the design space and fixing the operating ranges of input parameters in CCD-RSM-DF modelling and optimization process. In RSM modelling, $\mathrm{TiO}_{2}$ dosage, $\mathrm{ZnO}$ dosage, $\mathrm{H}_{2} \mathrm{O}_{2}$ dosage, reaction time (RT) and $\mathrm{pH}$ were chosen as input parameters, and the coded +1 (high) level and -1 (low) level were set at 0.2 and $0.7 \mathrm{~g} / \mathrm{L}, 0.2$ and $0.7 \mathrm{~g} / \mathrm{L}, 0.3$ and $0.9 \mathrm{~mL} / \mathrm{L}, 60$ and $180 \mathrm{~min}$ and 3 and 7 , respectively. Table 2 shows the central composite design

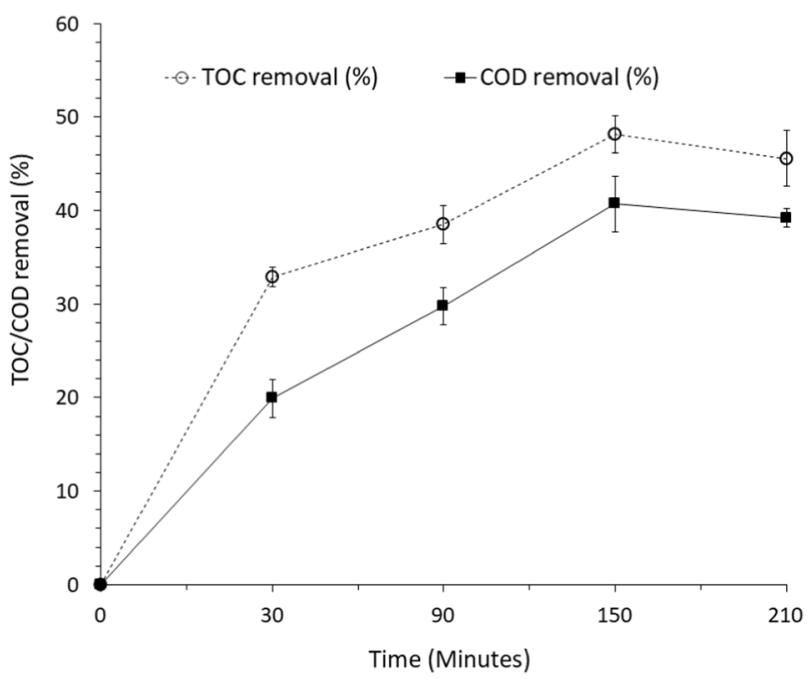

Fig. 3 TOC removal (\%) and COD removal (\%) at $\mathrm{TiO}_{2}$ dosage $0.45 \mathrm{~g} / \mathrm{L}, \mathrm{ZnO}$ dosage $0.45 \mathrm{~g} / \mathrm{L}, \mathrm{H}_{2} \mathrm{O}_{2}$ dosage $0.6 \mathrm{~mL} / \mathrm{L}$ and $\mathrm{pH} 6$ for different solar irradiation time layout and the respective response values generated from each experimental run. The COD removal ranges from 13.6 to $56.9 \%$, while the TOC removal lies between $27.1 \%$ to a maximum of $67.3 \%$.

\section{Analysis of variance (ANOVA) study}

In the present study, ANOVA was used for statistical analysis of the data to determine main and interaction effects between input factors and process responses. Tables 3 and 4 show the ANOVA modelling parameters for responsesurface generated second-order model for TOC removal and COD removal, respectively. Influence of independent variables on each response is demonstrated in these tables. All the insignificant terms (except the terms for hierarchy) with a $p$ value greater than 0.05 have been removed from the model. Lack of fit test checks whether the regression model fits well or not and compares the variation that is visible in the replicates with the variation present in the model. Significance of polynomial model terms and the model was assessed by the $p$ value (probability) with a $95 \%$ confidence level. Models with good fit should have $R^{2}$ value greater than 0.8 . In the present research, the predicted $R^{2}$ value for TOC and COD degradation was found to be 0.92 and 0.91 , respectively. The $R^{2}$ determines the amount of correlation between the predicted responses and experimental data. Large $R^{2}$ value (nearing 1) demonstrates decent agreement between the observed and calculated results.

The adequate precision (AP) fractions of COD and TOC response models in this study were found to be 64.3 and 53.4, respectively. This ratio measures the signal-tonoise ratio to estimate the validity of the regression models obtained. AP values above four are required to qualify the models to be used for process optimization and navigate the design space formulated by the central composite design (CCD). As per ANOVA results, COD and TOC models were found significant by $F$ test at $95 \%$ confidence level (Prob $<0.05)$. The response model $F$-ratio of 209.2 and 322.7 with low probability values $(($ Prob $>F)<0.05)$ shows that both models are significant enough to predict the response and optimum values. The difference between adjusted and predicted $R^{2}$ should be within 0.2 , which was satisfied with both models.

\section{CCD models in terms of actual and coded factors}

Table 5 shows CCD equations of TOC and COD removal $(\%)$ in coded and actual factor terms. Coded factor models provide more meaningful insight about the process than equations represented in terms of actual factors. In coded factors, the terms are normalized and depicted in relative weights, while in equations with actual factors, owing to the presence of units, the prominence of coefficients is

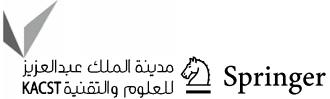


Table 2 Five-factor central composite design (CCD) matrix; input factors at actual levels and the corresponding experimental and predicted results

\begin{tabular}{|c|c|c|c|c|c|c|c|c|c|}
\hline \multirow[t]{2}{*}{ Run } & \multicolumn{5}{|l|}{ Input factors } & \multicolumn{2}{|c|}{ Experimental } & \multicolumn{2}{|l|}{ RSM-predicted } \\
\hline & $A: \mathrm{TiO}_{2}(\mathrm{~g} / \mathrm{L})$ & $B: \mathrm{ZnO}(\mathrm{g} / \mathrm{L})$ & $\begin{array}{l}C: \mathrm{H}_{2} \mathrm{O}_{2} \\
(\mathrm{~mL} / \mathrm{L})\end{array}$ & $D: \mathrm{pH}$ & $E: \mathrm{RT}(\min )$ & $\begin{array}{l}\text { TOC } \\
\text { removal } \\
(\%)\end{array}$ & $\begin{array}{l}\text { COD } \\
\text { removal(\%) }\end{array}$ & TOC removal (\%) & $\begin{array}{l}\text { COD } \\
\text { removal } \\
(\%)\end{array}$ \\
\hline 1 & 0.45 & 0.45 & 0.3 & 5 & 120 & 60.2 & 41.6 & 56.31 & 40.75 \\
\hline 2 & 0.45 & 0.45 & 0.6 & 5 & 120 & 61.1 & 53.9 & 60.50 & 50.97 \\
\hline 3 & 0.2 & 0.2 & 0.9 & 7 & 180 & 59.5 & 33.6 & 57.98 & 33.23 \\
\hline 4 & 0.7 & 0.7 & 0.9 & 3 & 60 & 44.8 & 34.6 & 42.39 & 33.29 \\
\hline 5 & 0.45 & 0.7 & 0.6 & 5 & 120 & 53.1 & 50.2 & 54.16 & 50.86 \\
\hline 6 & 0.2 & 0.7 & 0.9 & 7 & 180 & 62.2 & 37.2 & 59.35 & 37.49 \\
\hline 7 & 0.45 & 0.45 & 0.6 & 7 & 120 & 67.3 & 56.9 & 67.03 & 55.39 \\
\hline 8 & 0.7 & 0.2 & 0.9 & 7 & 180 & 62.1 & 37.9 & 64.32 & 37.98 \\
\hline 9 & 0.2 & 0.7 & 0.9 & 3 & 180 & 42.5 & 27.2 & 44.14 & 28.63 \\
\hline 10 & 0.45 & 0.45 & 0.6 & 5 & 60 & 57.1 & 43.7 & 56.46 & 42.46 \\
\hline 11 & 0.2 & 0.7 & 0.3 & 7 & 60 & 39.5 & 26.3 & 39.26 & 26.58 \\
\hline 12 & 0.7 & 0.2 & 0.9 & 3 & 60 & 41.9 & 23.8 & 41.03 & 23.07 \\
\hline 13 & 0.7 & 0.7 & 0.9 & 3 & 180 & 50.1 & 39.6 & 50.48 & 39.35 \\
\hline 14 & 0.2 & 0.2 & 0.3 & 7 & 180 & 42.2 & 29.9 & 45.99 & 28.38 \\
\hline 15 & 0.7 & 0.7 & 0.3 & 3 & 60 & 36.7 & 30.5 & 37.62 & 31.35 \\
\hline 16 & 0.7 & 0.2 & 0.3 & 7 & 60 & 47.2 & 30.1 & 47.17 & 29.98 \\
\hline 17 & 0.2 & 0.7 & 0.3 & 3 & 180 & 36.3 & 22.9 & 36.44 & 23.78 \\
\hline 18 & 0.45 & 0.45 & 0.6 & 3 & 120 & 54.2 & 46.7 & 53.97 & 46.54 \\
\hline 19 & 0.45 & 0.2 & 0.6 & 5 & 120 & 52.2 & 44.2 & 52.79 & 43.62 \\
\hline 20 & 0.7 & 0.2 & 0.3 & 7 & 180 & 57.3 & 36.3 & 55.26 & 36.04 \\
\hline 21 & 0.2 & 0.7 & 0.3 & 3 & 60 & 29.1 & 18.7 & 28.35 & 17.72 \\
\hline 22 & 0.7 & 0.7 & 0.3 & 3 & 180 & 43.6 & 37.4 & 45.71 & 37.41 \\
\hline 23 & 0.7 & 0.45 & 0.6 & 5 & 120 & 56.2 & 51.2 & 56.93 & 51.39 \\
\hline 24 & 0.45 & 0.45 & 0.6 & 5 & 120 & 57.1 & 48.1 & 60.50 & 50.97 \\
\hline 25 & 0.7 & 0.2 & 0.9 & 7 & 60 & 56.5 & 32.4 & 56.23 & 31.92 \\
\hline 26 & 0.2 & 0.2 & 0.3 & 3 & 60 & 27.1 & 13.6 & 26.98 & 13.46 \\
\hline 27 & 0.2 & 0.2 & 0.9 & 3 & 60 & 34.3 & 17.7 & 34.69 & 18.31 \\
\hline 28 & 0.2 & 0.2 & 0.3 & 3 & 180 & 35.3 & 19.9 & 35.07 & 19.52 \\
\hline 29 & 0.45 & 0.45 & 0.6 & 5 & 180 & 65.5 & 47.2 & 64.55 & 48.52 \\
\hline 30 & 0.2 & 0.2 & 0.3 & 7 & 60 & 38.5 & 20.3 & 37.90 & 22.32 \\
\hline 31 & 0.2 & 0.2 & 0.9 & 3 & 180 & 44.2 & 25.8 & 42.78 & 24.37 \\
\hline 32 & 0.2 & 0.7 & 0.9 & 3 & 60 & 35.3 & 23.6 & 36.05 & 22.57 \\
\hline 33 & 0.45 & 0.45 & 0.9 & 5 & 120 & 64.2 & 45.2 & 64.70 & 45.14 \\
\hline 34 & 0.2 & 0.7 & 0.3 & 7 & 180 & 48.7 & 32.8 & 47.35 & 32.64 \\
\hline 35 & 0.7 & 0.2 & 0.3 & 3 & 180 & 44.3 & 28.5 & 44.35 & 27.19 \\
\hline 36 & 0.7 & 0.7 & 0.3 & 7 & 180 & 56.8 & 47.2 & 56.63 & 46.26 \\
\hline 37 & 0.45 & 0.45 & 0.6 & 5 & 120 & 61.4 & 49.2 & 60.50 & 50.97 \\
\hline 38 & 0.45 & 0.45 & 0.6 & 5 & 120 & 58.5 & 52.5 & 60.50 & 50.97 \\
\hline 39 & 0.2 & 0.2 & 0.9 & 7 & 60 & 48.4 & 25.6 & 49.89 & 27.17 \\
\hline 40 & 0.2 & 0.7 & 0.9 & 7 & 60 & 51.3 & 32.4 & 51.26 & 31.43 \\
\hline 41 & 0.2 & 0.45 & 0.6 & 5 & 120 & 48.2 & 42.3 & 49.12 & 42.20 \\
\hline 42 & 0.45 & 0.45 & 0.6 & 5 & 120 & 59.4 & 49.3 & 60.50 & 50.97 \\
\hline 43 & 0.7 & 0.2 & 0.3 & 3 & 60 & 37.7 & 19.6 & 36.26 & 21.13 \\
\hline 44 & 0.7 & 0.7 & 0.3 & 7 & 60 & 47.2 & 40.1 & 48.54 & 40.20 \\
\hline 45 & 0.7 & 0.7 & 0.9 & 7 & 60 & 56.7 & 42.1 & 57.59 & 42.14 \\
\hline 46 & 0.7 & 0.2 & 0.9 & 3 & 180 & 49.1 & 27.6 & 49.12 & 29.12 \\
\hline
\end{tabular}


Table 2 (continued)

\begin{tabular}{|c|c|c|c|c|c|c|c|c|c|}
\hline \multirow[t]{2}{*}{ Run } & \multicolumn{5}{|l|}{ Input factors } & \multicolumn{2}{|c|}{ Experimental } & \multicolumn{2}{|l|}{ RSM-predicted } \\
\hline & $A: \mathrm{TiO}_{2}(\mathrm{~g} / \mathrm{L})$ & $B: \mathrm{ZnO}(\mathrm{g} / \mathrm{L})$ & $\begin{array}{l}C: \mathrm{H}_{2} \mathrm{O}_{2} \\
(\mathrm{~mL} / \mathrm{L})\end{array}$ & $D: \mathrm{pH}$ & $E:$ RT (min) & $\begin{array}{l}\text { TOC } \\
\text { removal } \\
(\%)\end{array}$ & $\begin{array}{l}\text { COD } \\
\operatorname{removal}(\%)\end{array}$ & TOC removal (\%) & $\begin{array}{l}\text { COD } \\
\text { removal } \\
(\%)\end{array}$ \\
\hline 47 & 0.7 & 0.7 & 0.9 & 7 & 180 & 67.1 & 47.1 & 65.68 & 48.20 \\
\hline 48 & 0.45 & 0.45 & 0.6 & 5 & 120 & 61.7 & 51.4 & 60.50 & 50.97 \\
\hline
\end{tabular}

Table 3 Analysis of variance (ANOVA) results of secondorder models for TOC removal

Table 4 Analysis of variance (ANOVA) results of secondorder models for COD removal

\begin{tabular}{lcrrrrll}
\hline Source & Sum of squares & $d f$ & Mean square & $F$ value & $p$ value & & \\
\hline Model & 5067.84 & 9 & 563.09 & 209.22 & $<0.0001$ & Significant & \\
$A-\mathrm{TiO}_{2}$ & 517.92 & 1 & 517.92 & 192.43 & $<0.0001$ & & \\
$B-\mathrm{ZnO}$ & 15.83 & 1 & 15.83 & 5.88 & 0.0202 & Mean & 50.23 \\
$C-\mathrm{H}_{2} \mathrm{O}_{2}$ & 597.24 & 1 & 597.24 & 221.91 & $<0.0001$ & $R^{2}$ & 0.9768 \\
$D-\mathrm{pH}$ & 1449.53 & 1 & 1449.53 & 538.57 & $<0.0001$ & Adj. $R^{2}$ & 0.9568 \\
$E-\mathrm{RT}$ & 556.07 & 1 & 556.07 & 206.61 & $<0.0001$ & Pred. $R^{2}$ & 0.9282 \\
$A C$ & 17.26 & 1 & 17.26 & 6.41 & 0.0156 & SD & 1.64 \\
$C D$ & 36.77 & 1 & 36.77 & 13.66 & 0.0007 & CV \% & 3.27 \\
$A^{2}$ & 201.20 & 1 & 201.20 & 74.76 & $<0.0001$ & Adeq. Prec. & 53.4 \\
$B^{2}$ & 177.72 & 1 & 177.72 & 66.03 & $<0.0001$ & & \\
Residual & 102.27 & 38 & 2.69 & & & & \\
Lack of fit & 85.30 & 33 & 2.58 & 0.7615 & 0.7175 & Not significant & \\
Pure error & 16.97 & 5 & 3.39 & & & & \\
Cor total & 5170.11 & 47 & & & & & \\
\hline
\end{tabular}

\begin{tabular}{lcrrrrll}
\hline Source & Sum of squares & $d f$ & Mean square & $F$ value & $p$ value & & \\
\hline Model & 6020.87 & 11 & 547.35 & 322.71 & $<0.0001$ & Significant & \\
$A-\mathrm{TiO}_{2}$ & 717.60 & 1 & 717.60 & 423.08 & $<0.0001$ & & \\
$B-\mathrm{ZnO}$ & 445.69 & 1 & 445.69 & 262.77 & $<0.0001$ & Mean & 36.16 \\
$C-\mathrm{H}_{2} \mathrm{O}_{2}$ & 97.92 & 1 & 97.92 & 57.73 & $<0.0001$ & $R^{2}$ & 0.9662 \\
$D-\mathrm{pH}$ & 666.18 & 1 & 666.18 & 392.77 & $<0.0001$ & Adj. $R^{2}$ & 0.9471 \\
$E-\mathrm{RT}$ & 312.03 & 1 & 312.03 & 183.96 & $<0.0001$ & Pred. $R^{2}$ & 0.9114 \\
$A B$ & 71.10 & 1 & 71.10 & 41.92 & $<0.0001$ & SD & 1.3 \\
$A C$ & 16.97 & 1 & 16.97 & 10.00 & 0.0032 & CV \% & 3.60 \\
$A^{2}$ & 45.57 & 1 & 45.57 & 26.87 & $<0.0001$ & Adeq. Prec. & 64.3 \\
$B^{2}$ & 36.28 & 1 & 36.28 & 21.39 & $<0.0001$ & & \\
$C^{2}$ & 148.05 & 1 & 148.05 & 87.29 & $<0.0001$ & & \\
$E^{2}$ & 78.37 & 1 & 78.37 & 46.21 & $<0.0001$ & & \\
Residual & 61.06 & 36 & 1.70 & & & & \\
Lack of fit & 36.13 & 31 & 1.17 & 0.2337 & 0.9955 & Not significant & \\
Pure error & 24.93 & 5 & 4.99 & & & & \\
Cor total & 6081.93 & 47 & & & & &
\end{tabular}

incomparable. Making inference about the relative effect between process variables is possible from coded factors equations. In the coded equation, the relative influence of the factors on response can be determined by comparing the factor coefficients.

\section{Effects of process variables as three-dimensional response surfaces}

Figure 4a shows the 3D response surface plots for COD removal $(\%)$ obtained by statistical analysis through 
Table 5 Final ANOVA **regression model equations for COD and TOC responses in terms of actual and coded factors

\begin{tabular}{lcc}
\hline & Coded factors equations & Actual factors equations \\
\hline COD & $=50.97+4.59 \times A+3.62 \times B+1.70 \times C+4.43 \times D$ & $-59.72+73.58 \times \mathrm{TiO}_{2}+57.38 \times \mathrm{ZnO}^{2}+110.35 \times \mathrm{H}_{2} \mathrm{O}_{2}+2.21$ \\
removal & $+3.03 \times E+1.49 \times A \times B-0.73 \times A \times C-4.17 \times A^{2}$ & $\times \mathrm{pH}+0.41 \times \mathrm{RT}+23.85 \times \mathrm{TiO}_{2} \times \mathrm{ZnO}^{2}-9.71 \times \mathrm{TiO}_{2} \times \mathrm{H}_{2} \mathrm{O}_{2}$ \\
$(\%)$ & $-3.72 \times B^{2}-7.52 \times C^{2}-5.47 \times E^{2}$ & $-66.79 \times \mathrm{TiO}_{2}^{2}-59.59 \times \mathrm{ZnO}^{2}-83.61 \times \mathrm{H}_{2} \mathrm{O}_{2}^{2}-0.001 \times \mathrm{RT}^{2}$ \\
TOC & $=60.5+3.9 \times A+0.68 \times B+4.19 \times C+6.53 \times D+4.04 \times E-0.74 \times$ & $=-24.84+129.19 \times \mathrm{TiO}_{2}+103.95 \times \mathrm{ZnO}^{2}+9.44 \times \mathrm{H}_{2} \mathrm{O}_{2}+2.19$ \\
removal & $A \times C+1.07 \times C \times D-7.48 \times A^{2}-7.03 \times B^{2}$ & $\times \mathrm{pH}+0.067 \times \mathrm{RT}^{2}-9.79 \times \mathrm{TiO}_{2} \times \mathrm{H}_{2} \mathrm{O}_{2}+1.78 \times \mathrm{H}_{2} \mathrm{O}_{2} \times \mathrm{pH}^{2}$ \\
$(\%)$ & & $-119.67 \times \mathrm{TiO}_{2}^{2}-112.47 \times \mathrm{ZnO}^{2}$ \\
\hline
\end{tabular}

(a)

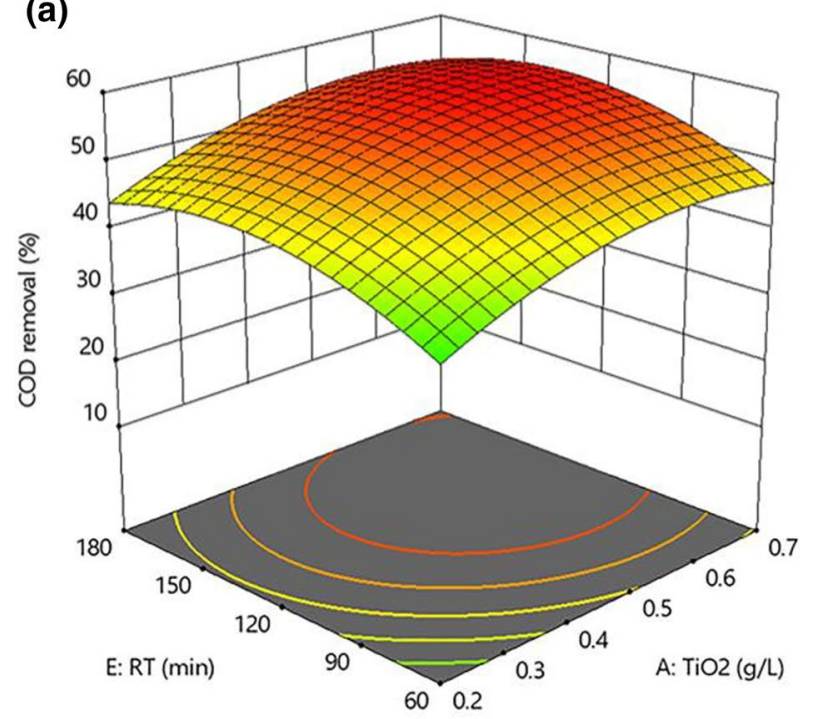

Fig. 4 a 3D plot for COD removal (\%) versus reaction time (RT) and $\mathrm{TiO}_{2}$ dosage at optimum settings of $\mathrm{pH}=7.0, \mathrm{ZnO}$ dosage $=0.502 \mathrm{~g} / \mathrm{L}$ and $\mathrm{H}_{2} \mathrm{O}_{2}$ dosage $=0.745 \mathrm{~mL} / \mathrm{L}$. b 3D-plot for TOC removal $(\%)$

Design-Expert software. The plots demonstrate the effects of reaction time (RT) and $\mathrm{TiO}_{2}$ dosage on the response when the other three variables kept constant at their optimum level $(\mathrm{ZnO}$ dosage $=0.502 \mathrm{~g} / \mathrm{L}, \mathrm{pH}=7$ and $\mathrm{H}_{2} \mathrm{O}_{2}=0.745 \mathrm{~mL} / \mathrm{L}$ ). The dome-shaped surface of the response indicates that the factor $\mathrm{A}$ : $\mathrm{TiO}_{2}$ dosage and factor E: reaction time (RT) have a quadratic effect on $\mathrm{COD}$ removal. The second-order terms $\left(A^{2}\right.$ and $\left.E^{2}\right)$ of the COD model in Table 5 validate this argument. The colour-coded optimum region (red) demonstrates that optimum COD removal is attained at $\mathrm{TiO}_{2}$ dosage $=0.535 \mathrm{~g} / \mathrm{L}$ and reaction time $(\mathrm{RT})=162 \mathrm{~min}$.

Figure $4 \mathrm{~b}$ demonstrates the RSM plot for TOC removal versus $\mathrm{ZnO}(\mathrm{g} / \mathrm{L})$ and $\mathrm{TiO}_{2}(\mathrm{~g} / \mathrm{L})$ at optimum settings of $\mathrm{H}_{2} \mathrm{O}_{2}$ dose $=0.745 \mathrm{~mL}, \mathrm{pH}=7$ and reaction time $(\mathrm{RT})=162.2 \mathrm{~min}$. The perfect dome-shaped surface indicates that the maximum TOC removal (\%) is achieved near the centre values of both $\mathrm{TiO}_{2}$ and $\mathrm{ZnO}$ factors. Optimum conditions from Table 6: $\mathrm{TiO}_{2}$ dosage $=0.535 \mathrm{~g} / \mathrm{L}, \mathrm{ZnO}$ (b)

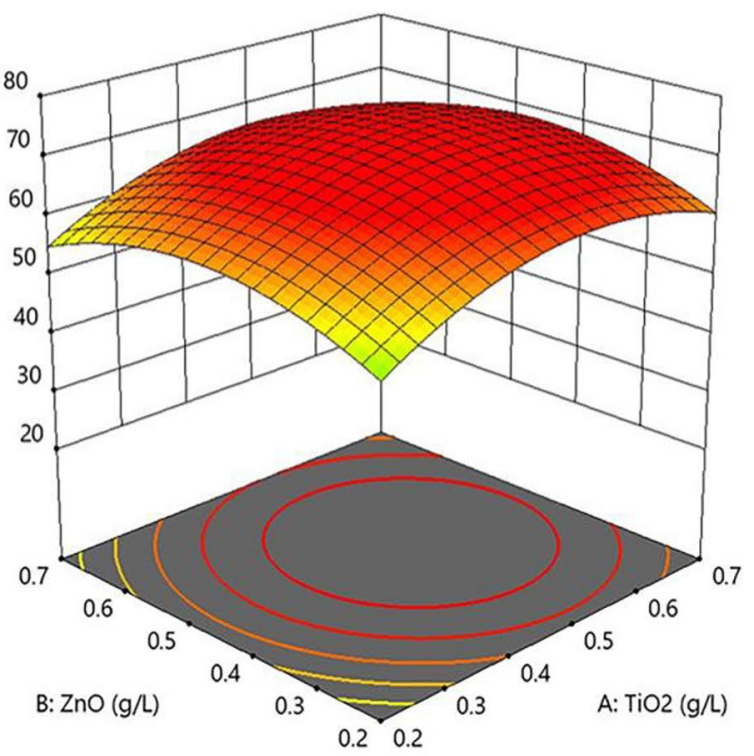

versus $\mathrm{ZnO}(\mathrm{g} / \mathrm{L})$ and $\mathrm{TiO}_{2}(\mathrm{~g} / \mathrm{L})$ at optimum settings of $\mathrm{H}_{2} \mathrm{O}_{2}$ dose $=0.745 \mathrm{~mL}, \mathrm{pH}=7$ and reaction time $(\mathrm{RT})=162.2 \mathrm{~min}$

dosage $=0.502 \mathrm{~g} / \mathrm{L}$ indicate that colour-coded peak appears near to the centre of the design space. The quadratic effects of both $\mathrm{TiO}_{2}$ and $\mathrm{ZnO}$ on TOC removal (\%) is visible from the curvature of the response and also from the secondorder terms of factors $A$ and $B$ in the coded equation of TOC removal (\%) (Table 5). It is observed that the removal efficiency is decreasing at higher concentration of catalysts due to the turbidity factor, which impedes the passing of solar light for the photocatalytic reaction (Malato et al. 2009).

\section{Synergistic effects of $\mathrm{TiO}_{2}$ and $\mathrm{ZnO}$ dosages}

The efficiency of the photocatalytic treatment process also depends on the ratio of $\mathrm{TiO}_{2}$ and $\mathrm{ZnO}$ dosages used in each experimental runs. Both OFAT and RSM studies suggested that the concentration of the catalyst should be near to 1:1 proportions and higher dosages decline the amount of organic removal. Optimum catalysts dosage is necessary to avoid turbidity and opacity due to excess amount, hindering 
Table 6 Optimum RSM and GA solutions for COD and TOC removal (\%) efficiencies and experimental validation results

\begin{tabular}{lllll}
\hline Optimization technique & Parameters & $\begin{array}{l}\text { Optimum solu- } \\
\text { tion }\end{array}$ & $\begin{array}{l}\text { Validation } \\
\text { results }\end{array}$ & Optimum condition \\
\hline RSM-DF optimization & COD removal (\%) & 55.55 & 51.2 & $\mathrm{TiO}_{2}$ dosage $=0.535 \mathrm{~g} / \mathrm{L}$ \\
& TOC removal (\%) & 72.58 & 68.6 & $\begin{array}{l}\mathrm{ZnO} \text { dosage }=0.502 \mathrm{~g} / \mathrm{L}, \mathrm{pH}=7 \\
\mathrm{H}_{2} \mathrm{O}_{2}=0.745 \mathrm{~mL} / \mathrm{L}, \mathrm{RT}=162 \mathrm{~min}\end{array}$ \\
& Desirability & 0.64 & & \\
GA optimization (Pareto optimal solu- & COD removal (\%) & 63.9 & 61.2 & $\mathrm{TiO}_{2}$ dosage $=0.51 \mathrm{~g} / \mathrm{L}$ \\
tion selected for validation) & TOC removal (\%) & 76.5 & 73.3 & $\begin{array}{l}\mathrm{ZnO} \text { dosage }=0.46 \mathrm{~g} / \mathrm{L}, \mathrm{pH}=6.9 \\
\mathrm{H}_{2} \mathrm{O}_{2}=0.89 \mathrm{~mL} / \mathrm{L}, \mathrm{RT}=179 \mathrm{~min}\end{array}$ \\
\hline
\end{tabular}

sunlight absorption during the photocatalytic process. The ' $A B$ ' interaction term between factors $A: \mathrm{TiO}_{2}$ and $B: \mathrm{ZnO}$ present in the coded equation in Table 5 shows their combined effect on COD removal (\%). The perfect dome-shaped curvature of response in Fig. $4 \mathrm{~b}$ indicates that both the factors simultaneously increase the removal efficiency near to the centre of the design space and at extreme ranges (four corners, -1 and +1 levels) the removal is minimal. The synergistic effect in $\mathrm{TiO}_{2}-\mathrm{ZnO}$ combination is due to the enrichment of charge transfer resulting in enhancement of hydroxyl radical production (Palominos et al. 2009). The second-order terms $\left(A^{2}\right.$ and $\left.B^{2}\right)$ in both TOC and COD model show the quadratic effect of $\mathrm{TiO}_{2}$ and $\mathrm{ZnO}$ on organic removal.

Even though due to catalyst dosage, a large number of active sites are generated, a limiting point is reached where the excessive amount resulting in turbidity reducing light penetration. The trade-off between these two competing phenomena decides the optimum catalysts dosage required for efficient photocatalytic degradation. In the present study, $\mathrm{TiO}_{2}$ dosage of $0.51 \mathrm{~g} / \mathrm{L}$ and $\mathrm{ZnO}$ dosage of $0.46 \mathrm{~g} / \mathrm{L}$ (RSMGA) were found to be optimum by achieving $61.2 \%$ removal of COD and $73.3 \%$ removal of TOC through validation experiments. Similar synergistic mineralisation performance was exhibited in a previous study where TOC removal efficiency (\%) was reached up to $95.3 \%$ for simulated solar photocatalysis of methylene blue removal (at $\mathrm{pH}=7$ ) using $\mathrm{TiO}_{2} / \mathrm{ZnO} /$ reduced graphene oxide composite (Nguyen et al. 2020). The results from the present study confirm that similar TOC and COD degradation of organic pollutants can be achieved at circumneutral $\mathrm{pH}$ of the seawater.

\section{Effects of pH}

The $\mathrm{pH}$ of the reaction mixture is a significant parameter in oxidation processes. Determining the most effective $\mathrm{pH}$ is still being debated widely because of the intermediates that were formed can result in different optimum $\mathrm{pH}$ values. In the current study, the optimum $\mathrm{pH}$ required for maximum TOC and COD degradation was found to be 6.9 (from RSM-GA optimization). Since adjusting a large volume of seawater $\mathrm{pH}$ to 6.9 in an $\mathrm{RO}$ desalination plant on a daily basis is problematic, experimental runs were also conducted without changing the initial $\mathrm{pH}$ of seawater, which was 7.8 (average). From the confirmation run (which was conducted at RSM-GA optimum setting), comparable organics removal efficiencies $(\mathrm{TOC}$ removal $=66.4 \%, \mathrm{COD}$ removal $=49.2 \%$ ) were observed when seawater $\mathrm{pH}$ kept constant (as target $\mathrm{pH}=8$ ). At circumneutral $\mathrm{pH}$, similar photocatalytic degradation efficiency was achieved in a previous study ( $\mathrm{Ji}$ et al. 2017) where degradation rate of diesel pollutants from seawater was reached up to $87.74 \%$ using $\mathrm{TiO}_{2} / \mathrm{ZrO}_{2}$ catalysts under visible light. Also, it was reported that, for solar photocatalytic disinfection of water, the degradation efficiency does not depend significantly on $\mathrm{pH}$ at ranges from 4 to 10 (Malato et al. 2016).

The positive coefficients of factor $\mathrm{D}(\mathrm{pH})$ in the model equations (coded factors) given in Table 5, show that $\mathrm{pH}$ has a tendency towards the upper limit (which was set as 7) for improving organic removal efficiency. At $\mathrm{pH}$ less than optimal conditions, generation of $\mathrm{OH}$ radicals become comparatively lower and lead to reduced oxidation of organics. $\mathrm{pH}$ also affects the position of conductance and valance bands, size of catalyst agglomeration and the charge on catalyst particles. Increasing the $\mathrm{pH}$ above optimal condition results in a lower generation of $\mathrm{H}^{+}$ions that further results in lower production of $\mathrm{OH}$ radicals (Jung et al. 2009). At acidic operational $\mathrm{pH}$, the surface charge for $\mathrm{TiO}_{2}$ becomes positive and exerts an attractive electrostatic force on anionic organic composites. Such polar attraction between negatively charged compounds and $\mathrm{TiO}_{2}$ enhances adsorption rate for succeeding photocatalysis. The surface charge property of the catalyst alters with deviation in $\mathrm{pH}$ of the solution. The point of zero charge (PZC) for Degussa-P25$\mathrm{TiO}_{2}$ is around 6.8 (Gogniat et al. 2006). In basic solution, the $\mathrm{TiO}_{2}$ surface is negatively charged, and when $\mathrm{pH}$ is lower than PZC, it is charged positively. The PZC value is altered when using $\mathrm{TiO}_{2}$ catalyst with $\mathrm{ZnO}$ powder. Hence, in the current study, the optimum organic removal is achieved at near-neutral $\mathrm{pH}$. Similar ranges of optimum values were reported by Kim et al. (2012) where they have demonstrated the synergistic effect of two different advanced oxidation processes $\left(\mathrm{TiO}_{2}\right.$ and Fenton-like reaction) resulted

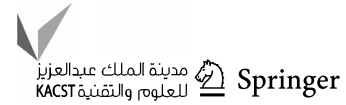


in enhanced $\mathrm{OH}$ production and drastic improvement in the oxidation of organic pollutant at circumneutral $\mathrm{pH}$ values.

\section{Effect of $\mathrm{H}_{2} \mathrm{O}_{2}$}

The influence of hydrogen peroxide on the organic removal efficiency was investigated in the range of $0.2-1.0 \mathrm{~mL} / \mathrm{L}$. The optimum dosage of $\mathrm{H}_{2} \mathrm{O}_{2}(=0.89 \mathrm{~mL} / \mathrm{L}$, from RSMGA optimization) and the positive coefficients of factor $\mathrm{C}$ $\left.\left(\mathrm{H}_{2} \mathrm{O}_{2}\right)\right)$ in the coded equations for TOC and COD removal (\%) as given in Table 5 indicate its positive influence on overall organics degradation. This is attributed to the ability of $\mathrm{H}_{2} \mathrm{O}_{2}$ for scavenging electron and enhancing the production of hydroxyl radicals (Jamil et al. 2019). Apart from preventing charge recombination, by accepting electrons, oxidants like $\mathrm{H}_{2} \mathrm{O}_{2}$ may dissociate into highly reactive radicals and thereby improve the mineralization efficiency (Diya'Uddeen et al. 2011). Oxidative degradation of organics is enhanced at the higher concentration of hydrogen peroxide leading to an overall increase in TOC and COD removal from the seawater.

\section{Effect of irradiation time}

Irradiation time has a significant role in decontamination of polluted water through heterogeneous photocatalysis. Irradiation time depends on the initial concentration and ionic state of various organic contaminants present in seawater as well as the type of catalyst used. Since seawater is very complex, it is not easy to degrade some contaminants into water and $\mathrm{CO}_{2}$. In the present study, the optimum irradiation time obtained from RSM-DF and RSM-GA simulation studies was $162 \mathrm{~min}$ and $179 \mathrm{~min}$, respectively. The optimum reaction time in this study is very less when compared with a previous photocatalytic degradation study (Zulfiqar et al. 2019), where the irradiation time was 540 min for optimum removal of phenol using $\mathrm{TiO}_{2}$ nanocatalysts. When compared with photocatalytic degradation of other industrial effluents, the irradiation time is significantly less in seawater treatment if the reaction is performed under optimum conditions. Factors such as photonic flux absorbed by $\mathrm{TiO}_{2} / \mathrm{ZnO}$, uniform distribution of catalysts in suspension, continuous flow of seawater through borosilicate tubular reactor contribute to achieve faster degradation of organics. The availability of high solar irradiance in the region $\left(670 \mathrm{Watts} / \mathrm{m}^{2}\right)$ also enhanced the overall degradation rate.

\section{Process optimization using response surface methodology (RSM) and desirability function (DF)}

In RSM, desirability function (DF) is used to optimize multiple responses in order to achieve maximal removal efficiencies of TOC and COD simultaneously. This approach enables to locate the optimal settings of the variables to attain the desired response. According to the numerical optimization steps in the Design-Expert (version 11) software, the desired goal for input variables ( $\mathrm{TiO}_{2}, \mathrm{ZnO}, \mathrm{H}_{2} \mathrm{O}_{2}$ dosages, $\mathrm{pH}$ and $\mathrm{RT}$ ) is chosen as "in range", while TOC and COD removal (\%) responses are defined as "maximum". The software combines the individual desirability to determine the best set of trade-offs. The programme then searches the design space to optimize desirability function based on the defined goals. Table 6 shows the values of optimum removal efficiencies forecasted by the model under optimum process operating conditions. Additional experiments were performed to confirm the validity of the prediction, revealing agreement between predicted and experimental results.

The TOC and COD percentage degradation obtained from RSM-DF analysis was found to be more than that resulted from OFAT analysis $(72.58 \%$ and $55.55 \%$ against $49.5 \%$ and $41.5 \%)$. This result shows that the study on interaction or interdependence of influencing factors is critical in a multivariate system. The synergistic or antagonistic effects of input factors on responses are not visible in the univariate investigation of OFAT analysis of any process. Solar photocatalytic seawater treatment is a complex multivariate process in which the system performance and organic removal efficiency are affected by a large number of synergistic and antagonistic interactions and main effects. While OFAT is suitable for screening and range finding, RSM provides more insight into the process behaviour.

\section{Genetic algorithm (GA) multiobjective optimization}

While RSM uses the desirability function (DF) approach for optimization, the genetic algorithm utilizes adaptive heuristic search techniques based on evolutionary ideas of genetics and natural selection (Bhatti et al. 2011). In complex processes like seawater solar photocatalysis, finding the global optima is cumbersome with conventional techniques as more often the solution tends to converge to local minima or maxima. Many technicals have found the superiority of GA over other optimization techniques as the GA solutions are always better due to convergence to global optimum (Betiku et al. 2016; Gou et al. 2018). In the current study, the optimization capacity of RSM-desirability function (RSM-DF) technique is compared with the solutions generated by GA multiobjective optimization. The TOC and COD removal models developed using RSM were implemented in an optimization process using gamultiobj solver, one of the multiobjective optimizers included in MATLAB ${ }^{\circledR}(2017 \mathrm{a})$ software. The GA solver stochastically searches through the domain space to attain the optimum solution. GA is an optimization technique developed based on the principle of natural evolution (Yasin et al. 2014). The GA strategy starts 
with the initialization of population known as chromosomes followed by fitness evaluation based on an objective function. The genetic propagation of chromosomes is based on the selection of the fittest and then through operators like crossover and mutation.

The five photocatalytic process factors which represent the input space of TOC and COD models (Table 2), were optimized using GA multiobjective solver from the optimization toolbox. This was attained through searching for the optimum solution that results in maximum removals of TOC and COD simultaneously. The RSM models of TOC and COD, developed in terms of actual factors (Table 5), were used as the fitness (objective) functions to evaluate the quality of the individual solution from the population. In terms of the GA toolbox implementation, the population type was selected as a double vector with crossover probability set as 0.9 . The adaptive-feasible mutation was utilized to create genetic diversity and enable GA to search for broader space. The population size, function tolerance and the maximum number of generations were set at 100 , 0.0001 and 100 , respectively. Finally, the optimal results were derived as a fully converged Pareto front.

The Pareto front (Fig. 5) generated by gamultiobj solver, demonstrates the trade-off between two competing objectives (TOC and COD removal) and determines the nondominated solutions. It includes those population members for which no other solution exists which is dominant than the Pareto set member. The GA optimizer in MATLAB ${ }^{\circledR}$ GA toolbox is essentially a minimization tool. Hence, the TOC and COD models (actual factors equations-Table 5) were negated when used as the objective function (fitness function). As depicted by the number of solution points in Fig. 5, the Pareto front gives a set of optimal solutions. Each point on the Pareto front is associated with a set of process factors (decision variables). In the current study, a set of 36 solutions were generated as optimal on the Pareto set. From Pareto optimal sets, one solution with maximum TOC removal $(73.3 \%)$ was selected for validation, and the results are shown in Table 6 . The degradation efficiency could be improved by using doped nanophotocatalysts (with metals or non-metals) to reduce the bandgap energy and thereby enabling the reaction in the visible region of the solar spectrum. When compared to RSM-DF optimization, GA multiobjective solutions identify more accurate TOC and COD removal efficiencies under different optimum conditions. The closeness of validation results to the optimum results of GA (Table 6), supports the superiority of RSM-GA over RSM-DF method of optimization.

\section{Conclusion}

In this advanced oxidation treatment study, efficiency and performance evaluation for TOC and COD removal from seawater have been investigated. Main effects and interaction among crucial process factors such as $\mathrm{TiO}_{2}$ dosage, $\mathrm{H}_{2} \mathrm{O}_{2}$ dosage, $\mathrm{pH}$, reaction time (RT) and $\mathrm{ZnO}$ dosage were assessed to evaluate optimum operational settings and treatment efficiency. Process optimization and performance evaluation were undertaken using response surface methodology-desirability function (RSM-DF) and RSM integrated with genetic algorithm (RSM-GA) approaches. In RSMDF method, organic removal, with a reaction time (RT)of $162 \mathrm{~min}, \mathrm{pH} 7.0, \mathrm{TiO}_{2}$ dosage of $0.535 \mathrm{~g} / \mathrm{L}, \mathrm{ZnO}$ dosage of $0.502 \mathrm{~g} / \mathrm{L}$ and $\mathrm{H}_{2} \mathrm{O}_{2}$ dosage of $0.745 \mathrm{~mL} / \mathrm{L}$ was found to be optimum by achieving $55.55 \%$ of COD removal and $72.58 \%$ of TOC removal. The obtained optimum values using RSMGA include a reaction time of $179 \mathrm{~min}, 0.51 \mathrm{~g} / \mathrm{L}$ of $\mathrm{TiO}_{2}$, $0.46 \mathrm{~g} / \mathrm{L}$ of $\mathrm{ZnO}$, pH 6.9 and $0.89 \mathrm{~mL} / \mathrm{L}$ of $\mathrm{H}_{2} \mathrm{O}_{2}$. RSMGA method gave higher organic removal rate at optimum
Fig. 5 Pareto-optimal set of solutions computed for multiobjective optimization of TOC removal efficiency (Objective-1) and COD removal efficiency (Objective-2)
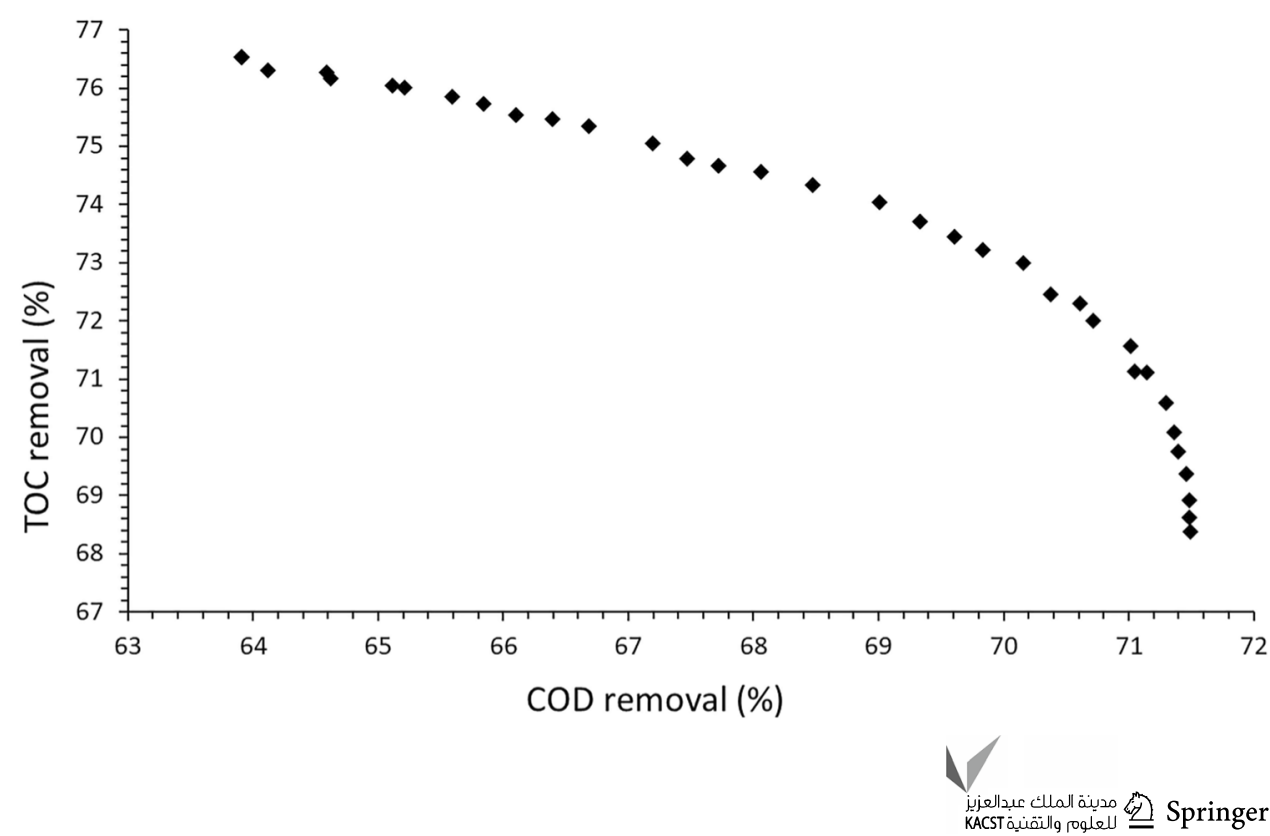
conditions different from RSM-DF (COD removal $=63.9 \%$ and TOC removal $=76.5 \%$ ). The results validate the performance of the multiobjective genetic algorithm for its convergence to the global optimum. The predicted RSMGA results correspond well with the experimental results (COD removal $=61.2 \%$ and $\mathrm{TOC}$ removal $=73.3 \%)$. The synergistic removal efficiency obtained in this work demonstrates that the combination of $\mathrm{TiO}_{2}$ catalyst with $\mathrm{ZnO}$ and $\mathrm{H}_{2} \mathrm{O}_{2}$ can be a feasible alternative for persistent organic removal. Thus, the solar mediated photocatalytic pretreatment of seawater can be applied as a sustainable technique for degradation of organics that foul RO membranes. The solar nanophotocatalysis of $\mathrm{TiO}_{2} / \mathrm{ZnO} / \mathrm{H}_{2} \mathrm{O}_{2}$ is a competitive method for decontaminating highly saline seawater by utilizing efficient renewable resources. Utilization of renewable solar energy coupled with optimum use of nanophotocatalysts enables this technique to be a unique treatment process for seawater reverse osmosis pretreatment and membrane fouling mitigation.

Funding The present work was not funded by any funding agency.

\section{Compliance with ethical standards}

Conflict of interest The authors declare that they have no conflict of interest.

Open Access This article is licensed under a Creative Commons Attribution 4.0 International License, which permits use, sharing, adaptation, distribution and reproduction in any medium or format, as long as you give appropriate credit to the original author(s) and the source, provide a link to the Creative Commons licence, and indicate if changes were made. The images or other third party material in this article are included in the article's Creative Commons licence, unless indicated otherwise in a credit line to the material. If material is not included in the article's Creative Commons licence and your intended use is not permitted by statutory regulation or exceeds the permitted use, you will need to obtain permission directly from the copyright holder. To view a copy of this licence, visit http://creativecommons.org/licenses/by/4.0/.

\section{References}

Ab Aziz NA, Palaniandy P, Aziz HA, Dahlan I (2016) Review of the mechanism and operational factors influencing the degradation process of contaminants in heterogenous photocatalysis. J Chem Res 40:704-712. https://doi.org/10.3184/174751916X14769 685673665

Abdollahi H, Noaparast M, Ziaedin S et al (2019) Prediction and optimization studies for bioleaching of molybdenite concentrate using artificial neural networks and genetic algorithm. Miner Eng 130:24-35. https://doi.org/10.1016/j.mineng.2018.10.008

Aljuboury DADA, Palaniandy P, Aziz HBA, Feroz S (2015) Treatment of petroleum wastewater using combination of solar photo-two catalyst $\mathrm{TiO}_{2}$ and photo-Fenton process. J Environ Chem Eng 3:1117-1124. https://doi.org/10.1016/j.jece.2015.04.012
Aljuboury DADA, Palaniandy P, Aziz HBA et al (2016) Evaluating photo-degradation of COD and TOC in petroleum refinery wastewater by using $\mathrm{TiO}_{2} / \mathrm{ZnO}$ photo-catalyst. Water Sci Technol 74:1312-1325. https://doi.org/10.2166/wst.2016.293

Amy G, Ghaffour N, Li Z et al (2017) Membrane-based seawater desalination: present and future prospects. Desalination 401:16-21. https://doi.org/10.1016/j.desal.2016.10.002

Azevedo EB, Tôrres AR, Aquino Neto FR, Dezotti M (2009) $\mathrm{TiO}_{2}$-photocatalyzed degradation of phenol in saline media in an annular reactor: hydrodynamics, lumped kinetics, intermediates, and acute toxicity. Braz J Chem Eng 26:75-87. https://doi. org/10.1016/j.apcatb.2004.06.014

Betiku E, Odude VO, Ishola NB et al (2016) Predictive capability evaluation of RSM, ANFIS and ANN: a case of reduction of high free fatty acid of palm kernel oil via esterification process. Energy Convers Manag 124:219-230. https://doi.org/10.1016/j. enconman.2016.07.030

Bhatti MS, Kapoor D, Kalia RK et al (2011) RSM and ANN modeling for electrocoagulation of copper from simulated wastewater: multi objective optimization using genetic algorithm approach. Desalination 274:74-80. https://doi.org/10.1016/j.desal.2011.01.083

Chatterjee S, Kumar A, Basu S, Dutta S (2012) Application of Response Surface Methodology for Methylene Blue dye removal from aqueous solution using low cost adsorbent. Chem Eng J 181-182:289-299. https://doi.org/10.1016/j.cej.2011.11.081

Desai KM, Survase SA, Saudagar PS et al (2008) Comparison of artificial neural network (ANN) and response surface methodology (RSM) in fermentation media optimization: case study of fermentative production of scleroglucan. Biochem Eng J 41:266-273. https://doi.org/10.1016/j.bej.2008.05.009

Dibaba OR, Lahiri SK, T'Jonck S, Dutta A (2016) Experimental and artificial neural network modeling of a Upflow Anaerobic Contactor (UAC) for biogas production from Vinasse. Int J Chem React Eng 14:1241-1254. https://doi.org/10.1515/ijcre-2016-0025

Diya'Uddeen BH, Daud WMAW, Abdul Aziz AR (2011) Treatment technologies for petroleum refinery effluents: a review. Process Saf Environ Prot 89:95-105. https://doi.org/10.1016/j. psep.2010.11.003

Gogniat G, Thyssen M, Denis M, Pulgarin C, Dukan S (2006) The bactericidal effect of $\mathrm{TiO}_{2}$ photocatalysis involves adsorption onto catalyst and the loss of membrane integrity. FEMS Microbiol Lett 258:18-24

Gou S, Nik VM, Scartezzini JL et al (2018) Passive design optimization of newly-built residential buildings in Shanghai for improving indoor thermal comfort while reducing building energy demand. Energy Build 169:484-506. https://doi.org/10.1016/j.enbui ld.2017.09.095

Hassani A, Khataee A, Fathinia M, Karaca S (2018) Photocatalytic ozonation of ciprofloxacin from aqueous solution using $\mathrm{TiO}_{2} /$ MMT nanocomposite: nonlinear modeling and optimization of the process via artificial neural network integrated genetic algorithm. Process Saf Environ Prot 116:365-376. https://doi.org/10.1016/j. psep.2018.03.013

Jamil A, Bokhari TH, Javed T et al (2019) Photocatalytic degradation of disperse dye Violet-26 using $\mathrm{TiO}_{2}$ and $\mathrm{ZnO}$ nanomaterials and process variable optimization. J Mater Res Technol. https://doi. org/10.1016/j.jmrt.2019.11.035

Ji Q, Yu X, Zhang J et al (2017) Photocatalytic degradation of diesel pollutants in seawater by using $\mathrm{ZrO}_{2}(\mathrm{Er} 3+) / \mathrm{TiO}_{2}$ under visible light. J Environ Chem Eng 5:1423-1428. https://doi.org/10.1016/j. jece.2017.01.011

Jiménez S, Micó MM, Arnaldos M et al (2017) Treatment of cleaning waters from seawater desalination reverse osmosis membranes for reutilization purposes. Part II: application of photo-Fenton and photocatalysis processes. J Water Process Eng 19:283-290. https ://doi.org/10.1016/j.jwpe.2017.08.008 
Jung YS, Lim WT, Park JY, Kim YH (2009) Effect of pH on Fenton and Fenton-like oxidation. J Environ Technol 30:183-190

Kaneva N, Bojinova A, Papazova K, Dimitrov D (2015) Photocatalytic purification of dye contaminated sea water by lanthanide $\left(\mathrm{La}^{3+}\right.$, $\left.\mathrm{Ce}^{3+}, \mathrm{Eu}^{3+}\right)$ modified ZnO. Catal Today 252:113-119. https://doi. org/10.1016/j.cattod.2014.12.008

Khedr MG (2011) Membrane fouling problems in reverse osmosis desalination plants. Desalin Water Reuse 10:8-17

Kim HE, Lee J, Lee H, Lee C (2012) Synergistic effects of $\mathrm{TiO}_{2}$ photocatalysis in combination with Fenton-like reactions on oxidation of organic compounds at circumneutral $\mathrm{pH}$. Appl Catal B Environ 115-116:219-224. https://doi.org/10.1016/j.apcatb.2011.12.027

Kumar A, Kumar V (2019) Modeling and optimization of fixed mode dual effect (photocatalysis and photo-Fenton) assisted Metronidazole degradation using ANN coupled with genetic algorithm. J Environ Manag. https://doi.org/10.1016/j.jenvman.2019.109428

Malato S, Fernández-Ibáñez P, Maldonado MI et al (2009) Decontamination and disinfection of water by solar photocatalysis: recent overview and trends. Catal Today 147:1-59. https://doi. org/10.1016/j.cattod.2009.06.018

Malato S, Maldonado MI, Fernández-Ibáñez P et al (2016) Decontamination and disinfection of water by solar photocatalysis: the pilot plants of the Plataforma Solar de Almeria. Mater Sci Semicond Process 42:15-23. https://doi.org/10.1016/j.mssp.2015.07.017

Matin A, Khan Z, Zaidi SMJ, Boyce MC (2011) Biofouling in reverse osmosis membranes for seawater desalination: phenomena and prevention. Desalination 281:1-16. https://doi.org/10.1016/j.desal .2011.06.063

Mukherjee R, Chakraborty R, Dutta A (2019) Comparison of optimization approaches (response surface methodology and artificial neural network-genetic algorithm) for a novel mixed culture approach in soybean meal fermentation. J Food Process Eng 42:1-10. https ://doi.org/10.1111/jfpe.13124

Nguyen CH, Tran ML, Van Tran TT, Juang RS (2020) Enhanced removal of various dyes from aqueous solutions by UV and simulated solar photocatalysis over $\mathrm{TiO}_{2} / \mathrm{ZnO} / \mathrm{rGO}$ composites. Sep Purif Technol. https://doi.org/10.1016/j.seppur.2019.115962

Palominos RA, Mondaca MA, Giraldo A et al (2009) Photocatalytic oxidation of the antibiotic tetracycline on $\mathrm{TiO}_{2}$ and $\mathrm{ZnO}$ suspensions. Catal Today 144:100-105. https://doi.org/10.1016/j.catto d.2008.12.031

Rubio D, Casanueva JF, Nebot E (2013) Improving UV seawater disinfection with immobilized $\mathrm{TiO}_{2}$ : study of the viability of photocatalysis (UV254/ $\left.\mathrm{TiO}_{2}\right)$ as seawater disinfection technology. J Photochem Photobiol A Chem 271:16-23. https://doi. org/10.1016/j.jphotochem.2013.08.002

Sen S, Dutta S, Guhathakurata S et al (2017) Removal of Cr(VI) using a cyanobacterial consortium and assessment of biofuel production. Int Biodeterior Biodegrad 119:211-224. https://doi. org/10.1016/j.ibiod.2016.10.050

Sharma N, Khanna R, Singh G, Kumar V (2017) Fabrication of 6061 aluminum alloy reinforced with $\mathrm{Si} 3 \mathrm{~N} 4 / \mathrm{n}-\mathrm{Gr}$ and its wear performance optimization using integrated RSM-GA. Part Sci Technol 35:731-741. https://doi.org/10.1080/02726351.2016.1196276

Tony MA, Zhao YQ, Purcell PJ, El-Sherbiny MF (2009) Evaluating the photo-catalytic application of Fenton's reagent augmented with $\mathrm{TiO}_{2}$ and $\mathrm{ZnO}$ for the mineralization of an oil-water emulsion. $\mathrm{J}$ Environ Sci Health Part A Toxic/Hazardous Subst Environ Eng 44:488-493. https://doi.org/10.1080/10934520902719894

Voutchkov Nikolay (2017) Pretreatment for reverse osmosis desalination. Elsevier, Amsterdam

Weinrich L, LeChevallier M, Haas CN (2016) Contribution of assimilable organic carbon to biological fouling in seawater reverse osmosis membrane treatment. Water Res 101:203-213. https:// doi.org/10.1016/j.watres.2016.05.075

Yang T, Peng J, Zheng Y et al (2018) Enhanced photocatalytic ozonation degradation of organic pollutants by $\mathrm{ZnO}$ modified $\mathrm{TiO}_{2}$ nanocomposites. Appl Catal B Environ 221:223-234. https://doi. org/10.1016/j.apcatb.2017.09.025

Yasin Y, Ahmad FBH, Ghaffari-Moghaddam M, Khajeh M (2014) Application of a hybrid artificial neural network-genetic algorithm approach to optimize the lead ions removal from aqueous solutions using intercalated tartrate- $\mathrm{Mg}-\mathrm{Al}$ layered double hydroxides. Environ Nanotechnol Monit Manag 1-2:2-7. https://doi. org/10.1016/j.enmm.2014.03.001

Zulfiqar M, Samsudin MFR, Sufian S (2019) Modelling and optimization of photocatalytic degradation of phenol via $\mathrm{TiO}_{2}$ nanoparticles: an insight into response surface methodology and artificial neural network. J Photochem Photobiol A Chem 384:112039. https://doi.org/10.1016/j.jphotochem.2019.112039

Publisher's Note Springer Nature remains neutral with regard to jurisdictional claims in published maps and institutional affiliations. 